University of Nebraska - Lincoln

DigitalCommons@University of Nebraska - Lincoln

Papers in the Earth and Atmospheric Sciences Earth and Atmospheric Sciences, Department

2013

\title{
Holocene variability in hydrology, vegetation, fire, and eolian activity in the Nebraska Sand Hills, USA
}

Jens Schmieder

University of Nebraska-Lincoln, jens.schmieder@gmail.com

Sherilyn C. Fritz

University of Nebraska-Lincoln, sfritz2@unl.edu

Eric C. Grimm

Illinois State Museum, eric.c.grimm@outlook.com

Kimberly C. Jacobs

University of Nebraska-Lincoln

Kendrick J. Brown

Canadian Forest Service

See next page for additional authors

Follow this and additional works at: https://digitalcommons.unl.edu/geosciencefacpub

Schmieder, Jens; Fritz, Sherilyn C.; Grimm, Eric C.; Jacobs, Kimberly C.; Brown, Kendrick J.; Swinehart, James; and Porter, Stephen C., "Holocene variability in hydrology, vegetation, fire, and eolian activity in the Nebraska Sand Hills, USA" (2013). Papers in the Earth and Atmospheric Sciences. 376.

https://digitalcommons.unl.edu/geosciencefacpub/376

This Article is brought to you for free and open access by the Earth and Atmospheric Sciences, Department of at DigitalCommons@University of Nebraska - Lincoln. It has been accepted for inclusion in Papers in the Earth and Atmospheric Sciences by an authorized administrator of DigitalCommons@University of Nebraska - Lincoln. 


\section{Authors}

Jens Schmieder, Sherilyn C. Fritz, Eric C. Grimm, Kimberly C. Jacobs, Kendrick J. Brown, James Swinehart, and Stephen C. Porter 


\title{
Holocene variability in hydrology, vegetation, fire, and eolian activity in the Nebraska Sand Hills, USA
}

\author{
Jens Schmieder,' Sherilyn C. Fritz,' Eric C. Grimm, ${ }^{2}$ Kimberly C. Jacobs, ' \\ Kendrick J. Brown, ${ }^{3}$ James B. Swinehart, ${ }^{4}$ and Stephen C. Porter ${ }^{5}$ \\ I. Department of Earth and Atmospheric Sciences, University of Nebraska - Lincoln, USA \\ 2. Illinois State Museum, Research and Collections Center, USA \\ 3. Canadian Forest Service, Canada \\ 4. School of Natural Resources, University of Nebraska - Lincoln, USA \\ 5. Fish \& Wildlife Branch, Saskatchewan Ministry of Environment, Canada
}

Corresponding author - Jens Schmieder, Department of Earth and Atmospheric Sciences, University of Nebraska-Lincoln, 2 I 4 Bessey Hall, Lincoln NE 68588- 0340, USA; email jens.schmieder@gmail.com

\begin{abstract}
This study combined multiple aquatic and terrestrial proxies, including diatoms, pollen, grain size, and bulk-sediment chemistry to reconstruct the history of three lake sites located in the central Sand Hills of Nebraska, USA. Long-term changes in effective moisture are evident at all sites, with significant changes occurring at $\sim 6000, \sim 4000$, and $\sim 2000$ cal. yr BP. Both aquatic and terrestrial indicators suggest that effective moisture was low between 10,000 and $\sim 6000$ cal. yr BP, and that this time interval was the driest period of the Holocene. The dominance of benthic and tychoplanktic diatom taxa indicates relatively shallow lake-level, high sand influx indicates moderately high eolian activity, and the pollen assemblage suggests xeric grasslands with abundant mud flats. About 6000 cal. yr $\mathrm{BP}$, all three sites experienced an increase in effective moisture. Lake-level rise is indicated by increases in planktic and tychoplanktic diatoms relative to benthic taxa, while greater abundance of grass pollen and charcoal, and decreased eolian flux indicate stabilized dunes with dense vegetation sufficient to fuel local fires. A significant hydrologic shift recorded at all sites occurred at $\sim 4000$ cal. $y r$ BP.This event was characterized by substantial lake-level rise, yet decreased grass cover and fire frequency, and increased eolian activity. Water-table rise may have been caused by a combination of factors including: (I) formation of dune-dams that blocked old drainage channels, (2) reduced grass cover and hence reduced evapotranspiration, and (3) changes in the frequency and duration of drought. The most likely cause(s) of the differential response of the terrestrial and aquatic systems at this time is not clear, none-theless the late Holocene was not nearly as dry as the interval prior to $6000 \mathrm{cal}$. yr BP.The last 2000 yr were characterized by several short-term fluctuations in lake level, including an interval of drought between 950 and 750 cal. yr BP, coincident with increased eolian activity during the latter part of the Medieval Climatic Anomaly.
\end{abstract}

Keywords: diatoms, drought, Holocene climate change, lakes, Nebraska Sand Hills, pollen

\section{Introduction}

A number of studies have examined Holocene climatic change and the spatial and temporal patterns of drought in the Great Plains of North America (e.g. Fritz et al., 2000; Grimm et al., 2011; Miao et al., 2007; Woodhouse and Overpeck, 1998). In the central Great Plains, much of the published research is based on geomorphic reconstructions from widespread eolian sand dune and loess deposits, such as the Nebraska Sand Hills. Effective moisture (precipitation minus evaporation, $\mathrm{P}-\mathrm{E}$ ) controls the density of vegetation cover, which is the key limitation on eolian activity (Muhs and Maat, 1993). Today, sufficient monsoonal moisture from the Gulf of Mexico sustains vegetation that stabilizes the extensive dune fields across the region (Loope et al., 1995). However, at various times during the Holocene, the Nebraska Sand Hills experienced a series of recurring and long-lasting droughts that caused the loss of vegetation cover and subsequent mobilization of large portions of the dune field (e.g. Goble et al., 2004; Nicholson and Swinehart, 2005). The timing and frequency of these droughts is complex, but recent studies that are based on optically stimulated luminescence (OSL), a technique that measures the time elapsed since quartz grains were last exposed to sunlight, reveal at least four broad periods of increased dune activity occurring at approximately $9000-6600 \mathrm{yr}$ BP, $\sim 3800 \mathrm{yr}$ BP, $\sim 2500$ yr BP, and $\sim 850$ yr BP (e.g. Goble et al., 2004; Miao et al., 2007).

Eolian deposits record dune-mobilization events, but they do not provide continuous records of moisture change, nor do they indicate the magnitude of drought necessary to reactivate dunes. On the other hand, lake sediments may record high frequency (yearly to multidecadal) changes in effective moisture; and climate proxies from lake sediments, such as diatoms and pollen, in conjunction with eolian records, may indicate the climatic triggers necessary for dune mobilization. In addition, these aquatic and terrestrial proxies may provide a comprehensive reconstruction of landscape change in response to drought.

The groundwater-table is high across the Nebraska Sand Hills, and a large number of shallow lakes, averaging 0.8 to 1.2 
m (McCarraher, 1977), ponds, and wetlands occur in interdunal swales and valleys. These aquatic habitats cover about $10 \%$ of the regional landscape (Schmieder, 2009). More than 1000 lakes are located in the western portion of the Sand Hills alone (Loope and Swinehart, 2000), which is the driest part of the region. Evidence suggests that dune blockage of drainage networks during prolonged arid intervals created many of these lakes and wetlands (Loope and Swinehart, 2000; Loope et al., 1995). In the Crescent Lake region of western Nebraska (Figure 1), dune dams blocked two large valley systems prior to 10,000 cal. yr BP, thereby raising the water-table of the HighPlains aquifer as much as $25 \mathrm{~m}$ over an area of $7000 \mathrm{~km} 2$ and creating a series of lakes and wetlands (Loope et al., 1995). A subsequent down-gradient episode of dune blockage about 4000 cal. yr BP changed the water-table gradient and is hypothesized to have produced a subsequent rise in water level in interdunal basins.

Here we present high-resolution multiproxy reconstructions from interdunal lakes in the north-central part of the Nebraska Sand Hills. We use these records to evaluate the timing and frequency of drought during the Holocene and also the potential role of dune blockage in causing lake-level change. Our primary study site is Beaver Lake, Nebraska, which was analyzed for diatoms, pollen, charcoal, and grain size. We use these proxies to reconstruct the history of the aquatic ecosystem and of the surrounding terrestrial environment (vegetation, fire, and eolian history). We also compare the Beaver Lake record with two other Sand Hill lakes that were analyzed for diatoms, mass-percent sand, and carbon fractions to establish whether observed patterns of lake-level variation were regional in extent or were site specific.

\section{Study sites}

The Nebraska Sand Hills, which extend over an area of $\sim 50,000 \mathrm{~km} 2$ with dunes reaching a height of $130 \mathrm{~m}$, form the largest dune field in the Western Hemisphere (Loope and Swinehart, 2000; Nicholson and Swinehart, 2005; Swinehart, 1990). Strong winds characterize this drought-prone region. These winds often exceed the critical velocity for sand entrainment (5 m/s) (Muhs et al., 1997), which in modern times and the recent past often resulted in sand drifts and blowouts. Studies have shown that these winds were powerful enough to shift entire dune systems across the landscape during prolonged droughts of the Holocene (e.g. Loope et al., 1995).

A large precipitation gradient, from about $400 \mathrm{~mm} / \mathrm{yr}$ in the west to over $600 \mathrm{~mm} / \mathrm{yr}$ in the east, is a key feature of the Sand Hills, affecting vegetation distribution and evapotranspiration across the region (Wilhite and Hubbard, 1998). This decrease in moisture from east to west is in large part the result of (1) the Rocky Mountains to the west creating a rain shadow across the Sand Hills region by blocking off moisture derived from the Pacific Ocean, and (2) increasing distance from the Gulf of Mexico, the origin of maritime tropical air masses that bring most precipitation to the Great Plains. Average annual temperatures range from $9.5^{\circ} \mathrm{C}$ in the east to slightly less than $9^{\circ} \mathrm{C}$ in the west (Wilhite and Hubbard, 1998).

Beaver Lake $\left(42^{\circ} 27^{\prime} 35^{\prime \prime} \mathrm{N}, 100^{\circ} 40^{\prime} 08^{\prime \prime} \mathrm{W}\right.$, elev. $\left.907 \mathrm{~m}\right)$ lies within the north-central portion of the Sand Hills in an interdunal valley between stabilized mega-barchan dunes (Figure 1). Maximum water depth (zmax) is about $3.5 \mathrm{~m}$, and the lake is connected to Rat Lake to the east. East and West Twin Lakes $\left(42^{\circ} 24^{\prime} 30^{\prime \prime} \mathrm{N}, 101^{\circ} 26^{\prime} 20^{\prime \prime} \mathrm{W}\right.$, elev. $1042 \mathrm{~m}$ and $1046 \mathrm{~m}$, respectively) are located about $60 \mathrm{~km}$ west of Beaver Lake. Elongate dunes reaching heights of more than $60 \mathrm{~m}$ surround these two lakes. East Twin Lake is presently dry because of artificial drainage.

Because of shallow depth and exposure to strong winds, most Sand Hill lakes do not thermally stratify and are nearly isothermal, regardless of season (La Baugh, 1986). The lakes tend to be turbid, with Secchi disk transparency commonly $<0.5 \mathrm{~m}$; and despite shallow depths, the $1 \%$ level of surface light generally does not penetrate to the bottom. Sand Hill lakes also commonly show seasonal and interannual variation in lake level in response to variability in effective moisture (Bennett et al., 2007).

\section{Methods}

Field

Beaver Lake was cored with a Wright square-rod piston corer (5 cm diameter) in July 1995 from the deepest part of the basin. Cores from the Twin Lakes were obtained by vibracoring between 1999 and 2006. One vibracore was taken from the edge of West Twin, while the core from East Twin was taken from the center of the lake (Figure 1).

\section{Chronology}

Chronology is based on accelerator mass spectrometry (AMS) radiocarbon dates of terrestrial charcoal, seeds, plant fragments, and bulk sediment (Table 1). The ${ }^{14} \mathrm{C}$ dates from Beaver Lake are all on macrofossils from terrestrial plants or emergent aquatics or on charcoal, which is necessarily of terrestrial origin. From Great Plains sites, these materials have generally provided accurate ages with no in-built age or old-carbon reservoir (Grimm, 2011; Grimm et al., 2009). Some of the ${ }^{14} \mathrm{C}$ ages from Twin Lakes are on bulk sediment, which often has a significant old-carbon reservoir. From the Great Plains, this reservoir derives from carbonate rocks (limestone and dolomite) and from carbonaceous rocks, especially shale, lignite, and coal, which are widespread in the Great Plains. The siliceous sands of the Sand Hills are not a source of these carbonaceous contaminants; nevertheless, waters of Sand Hills lakes tend to be alkaline with high concentration of bicarbonate and carbonate ions (Bleed and Ginsberg, 1998), thus the potential exists for a 'hardwater' reservoir effect. However, the bulk-sediment dates are not consistently out of line with the dates on plant macrofossils and charcoal, therefore there does not appear to be a significant old-carbon reservoir. Perhaps the shallowness of the lakes and the exposure to wind keeps the waters well mixed with atmospheric $\mathrm{CO}_{2}$ and in equilibrium with atmospheric $\Delta^{14} \mathrm{C}$. Small reservoir effects have also been observed in shallow, marl-producing lakes (Grimm et al., 2009).

Age models (Figure 2) were developed for the three sites with the Bacon program of Blaauw and Christen (2011). Bacon models accumulation rates with a Bayesian autoregressive process and generates $95 \%$ confidence limits and median probabilities for interpolated ages. Each core was divided into $10 \mathrm{~cm}$ increments, and accumulation rates were modeled for each increment, with accumulation-rate priors set to $10-18 \mathrm{yr} / \mathrm{cm}$. Bacon calibrates the input radiocarbon ages, and the calibration was based on the IntCal09 calibration curve (Reimer et al., 2009). For convenience, calibrated ages from CALIB 6.0 (Stuiver and Reimer, 1993) are provided in Table 1; however, these are calibrated with no Bayesian accumulation-rate constraints and were not the ages used for generating the age model.

\section{Diatoms}

Diatom analyses at decadal to century scale were carried out from core sediments (1-4 cm intervals). For diatom preparation, the samples were homogenized prior to subsampling and processed in hydrochloric acid (10\%) to oxidize any accumulated carbonates. Then samples were treated with cold hydrogen peroxide $(30 \%)$ to digest organic matter, and finally samples were rinsed several times with distilled water until free of peroxide. The final slurries were evenly settled on cover slips using a pipette and dried before being mounted 

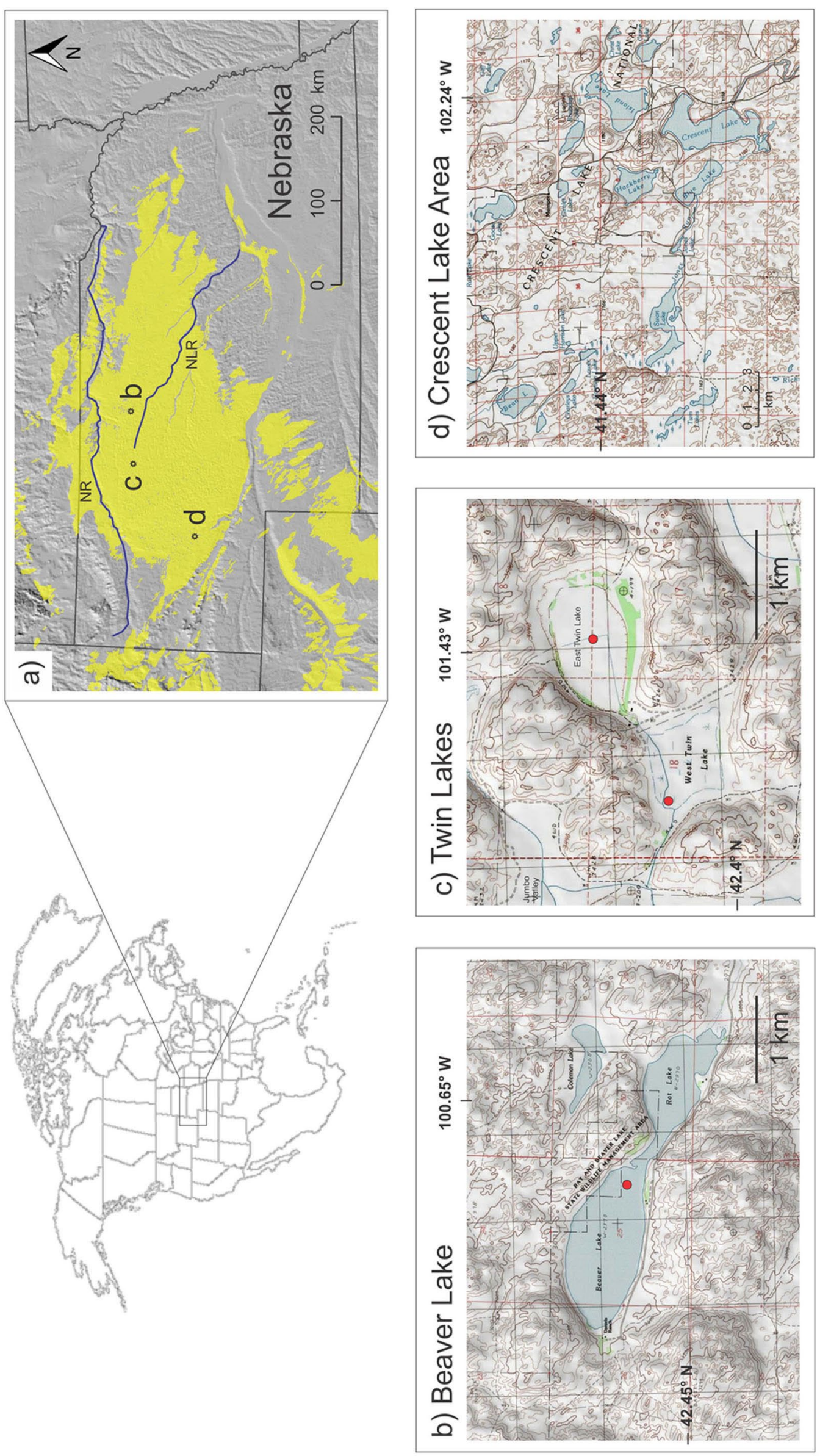

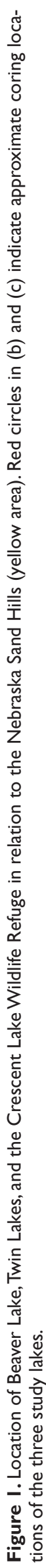


Table I. Radiocarbon ages and calibrated age equivalents used in determining age models for Beaver Lake, West Twin, and East Twin.

\begin{tabular}{|c|c|c|c|c|c|}
\hline Depth (cm) & Lab no. & Material & ${ }^{14} C_{y r} \mathrm{BP}$ & $\begin{array}{l}\text { 2-o range } \\
\text { (cal.yr BP) }\end{array}$ & $\begin{array}{r}\text { Median } \\
\text { (cal.yr BP) }\end{array}$ \\
\hline \multicolumn{6}{|l|}{ Beaver Lake } \\
\hline $399-403$ & CAMS-18863 & Charcoal & $1055 \pm 35$ & $923-1055$ & 964 \\
\hline $484-486$ & CAMS-42475 & 2 Schoenoplectus seeds, charcoal & $1740 \pm 50$ & $|538-| 8||$ & 1652 \\
\hline $519-520$ & CAMS-18865 & Schoenoplectus seed, charcoal & $3125 \pm 35$ & $3260-3442$ & 3355 \\
\hline $552-554$ & CAMS-42476 & 20 Sagittaria seeds & $3440 \pm 50$ & $3578-3835$ & 3704 \\
\hline $650-652$ & CAMS-42477 & 5 Schoenoplectus seeds, 3 Chenopodium seeds & $4480 \pm 50$ & $4894-5308$ & 5145 \\
\hline $650-652$ & CAMS-42478 & Charcoal & $4550 \pm 50$ & $504 I-5444$ & 5174 \\
\hline 979 & CAMS-25282 & cf. Schoenoplectus rhizome & $10,980 \pm 60$ & $|2,675-| 3,07 \mid$ & 12,847 \\
\hline \multicolumn{6}{|c|}{ West Twin Lake } \\
\hline $162-163$ & OS-55762 & Charcoal & $395 \pm 35$ & $319-512$ & 462 \\
\hline $221-222$ & OS-55693 & Undiff. plant \& wood frag. & $805 \pm 45$ & $666-891$ & 722 \\
\hline $506-507$ & OS-55723 & Undiff. plant \& wood frag. & $5120 \pm 55$ & $5734-5989$ & 5847 \\
\hline $506-507$ & OS-55763 & Bulk sediment & $5400 \pm 45$ & $6016-6293$ & 6216 \\
\hline $538-539$ & OS-59797 & Undiff. plant \& wood frag. & $5510 \pm 110$ & $5998-6531$ & 6306 \\
\hline $570-57 \mid$ & OS-5749| & Undiff. plant \& wood frag. & $6720 \pm 45$ & $7507-7666$ & 7588 \\
\hline $636-637$ & OS-56173 & Undiff. plant \& wood frag. & $7560 \pm 610$ & 7178-9909 & 8470 \\
\hline \multicolumn{6}{|l|}{ East Twin Lake } \\
\hline $4 I-42$ & OS-62024 & Wood, charcoal & $1040 \pm 80$ & $781-1170$ & 957 \\
\hline $68-69$ & OS-60100 & Undiff. plant \& wood frag. & $2130 \pm 40$ & 1995-2303 & 2113 \\
\hline $105-106$ & OS-6I478 & Bulk sediment & $2660 \pm 40$ & $2739-2849$ & 2774 \\
\hline$|40-14|$ & OS-60302 & Bulk sediment & $3480 \pm 25$ & $3689-3834$ & 3760 \\
\hline $221-222$ & OS-60I25 & Charcoal & $4040 \pm 30$ & $4423-4781$ & 4501 \\
\hline $277-278$ & OS-60I26 & Charcoal & $5050 \pm 30$ & $5726-5901$ & 5823 \\
\hline
\end{tabular}

onto slides with Naphrax®. At least 300 diatom valves from each interval were counted in transects under oil immersion on a Zeiss Axioscop 2 plus light microscope with a $100 \times$ objective. Samples were counted every $2 \mathrm{~cm}$ for Beaver Lake for an average resolution between samples of about 35 cal. yr. East Twin Lake was also counted in $2 \mathrm{~cm}$ intervals with a resolution averaging $\sim 40$ cal. yr, while for West Twin Lake sample intervals were examined in $1 \mathrm{~cm}$ intervals for the first $5600 \mathrm{cal}$. yr BP (approx. equal to $15 \mathrm{cal}$. yr average) and in $4 \mathrm{~cm}$ increments beyond that point (equivalent to $33.5 \mathrm{cal}$. yr average). Primary taxonomic references used for all lakes were Patrick and Reimer $(1966,1975)$ and Krammer and Lange-Bertalot (1986, 1988, 1991a, 1991b). Species percent abundances were plotted against the developed chronology to determine changes in species abundances through time using the software C2 V.1.6 (Juggins, 2009).

Diatom zonations were defined based on stratigraphically constrained cluster analysis by incremental sum of squares (CONISS) algorithm (Grimm, 1987) and by using the brokenstick method with the software psimpoll 4.10 (Bennett, 2002). Prior to analysis, species relative abundance (> $2 \%$ ) data were square-root transformed, and the resultant dissimilarity coefficient calculated in chord distance.

\section{Grain size, percent weight sand, and carbon fractions}

A grain-size analysis was performed on the Beaver Lake sediments at $2 \mathrm{~cm}$ intervals using a Coulter Laser Diffraction unit (Model LS100Q). We prepared $0.5 \mathrm{~g}$ of wet sediment for ev- ery sample and, if secondary carbonates were present $(>0.1 \%$ inorganic carbon by finally weight again), extracted carbonates with a $10 \% \mathrm{HCl}$ solution. Organic matter was removed by adding $3 \mathrm{ml}$ of concentrated hydrogen peroxide (30\%) to each sample. For the removal of biogenic silica, we added $10 \mathrm{ml}$ of $1 \mathrm{M}$ $\mathrm{NaOH}$. The machine output separates the sand samples into five different size fractions (D10, D25, D50, D75, and D90). To estimate organic matter and carbonate content of the Beaver Lake sediment (Dean, 1974), volumetric samples $(0.5 \mathrm{ml})$ were dried overnight at $100^{\circ} \mathrm{C}$, weighed, and ignited at $500^{\circ} \mathrm{C}$ for 1 $\mathrm{h}$, weighed, ignited at $900^{\circ} \mathrm{C}$ for $1 \mathrm{~h}$, and finally weighed again. Samples were cooled in a desiccator. Controls of ash-free filter paper and laboratory grade $\mathrm{CaCO}_{3}$ were run with each batch to check for complete burn of organic matter at $500^{\circ} \mathrm{C}$ and complete dissociation of $\mathrm{CaCO}_{3}$ at $900^{\circ} \mathrm{C}$.

Sand concentrations, expressed in \% dry weight, were analyzed in $4 \mathrm{~cm}$ increments for East Twin Lake. Samples were treated with $\mathrm{HCl}$ (hydrochloric acid) to remove carbonates and $\mathrm{H}_{3} \mathrm{PO}_{4}$ (phosphoric acid) to eliminate organic matter. Subsequently, diatom frustules and siliceous chrysophyte cysts were removed by wet sieving through a $62 \mu \mathrm{m}$ sieve and a $1 \mathrm{~min}$ application of a 3\% HF solution at room temperature. Finally, the samples were decanted, washed three times, and then dried.

East and West Twin Lakes were analyzed for total carbon (TC) and total inorganic carbon (TIC) content from freezedried samples. TC was measured by dry combustion analysis, using a Costech Analytical ECS 4010. Prior to analysis, samples were treated with $\mathrm{H}_{3} \mathrm{PO} 4$ (phosphoric acid) to remove all 

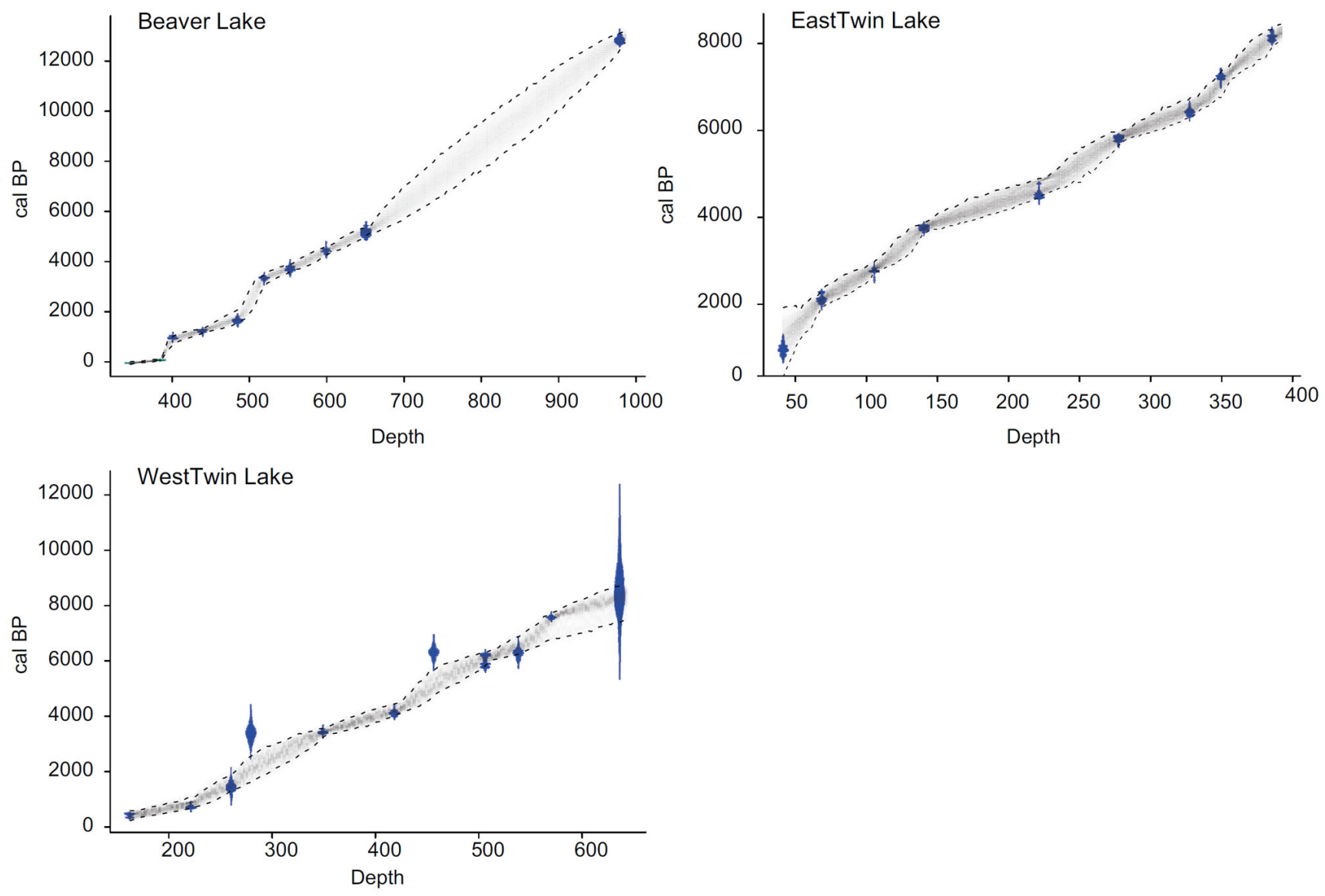

Figure 2. Posterior BACON age-depth models (Blaauw and Christen, 20II) of Beaver Lake and Twin Lakes (gray), overlaying the calibrated distributions of the individual dates (blue). Gray lines indicate the model's $95 \%$ probability intervals, and intensity of gray indicates the concentration of probability. Ages are based on AMS dates of terrestrial grass charcoal and seeds.

inorganic carbon. TIC content was determined by coulometric titration, using a CM 5012 UIC coulometer, with $\mathrm{CaCO}_{3}$ as a control standard. To each sediment sample, $5 \mathrm{ml} \mathrm{H}_{3} \mathrm{PO}_{4}$ (20\%) was added to convert TIC into $\mathrm{CO}_{2}$ gas, which is quantitatively absorbed in the coulometer cell. The generated current during coulometric titration is proportional to the amount of carbon. The linear range was from $0.01 \mu \mathrm{g}$ to $100 \mathrm{mg}$ C.

\section{Pollen and charcoal}

Samples for pollen analysis were prepared with standard procedures (Fægri et al., 1989) and mounted in silicone oil. Pollen sums of at least 300 upland types were counted. Pollen data were plotted as relative percentages using the software C2 V.1.6 (Juggins, 2009). To reconstruct the incidence of past fire, charcoal fragments were sieved from $0.5 \mathrm{ml}$ subsamples from the $1 \mathrm{~cm}$ slices. Samples were gently sieved through a $180 \mu \mathrm{m}$ screen, and the coarse fraction retained was examined for charcoal under a dissecting microscope at 20× magnification. The microscope was fitted with a video mount, and the charcoal fragments analyzed using NIH IMAGE software to measure length, width, and total area. Charcoal concentration $(\mathrm{mm} 2 / \mathrm{cm} 3)$ was determined for each sample.

\section{Results and discussion}

Lake-level, vegetation, fire, and eolian history

Multiple proxies analyzed from the Beaver Lake core provide an integrated picture of the history of the lake and the surrounding watershed. We couple these reconstructions with complementary data from the Twin Lakes and with other regional studies of eolian history to evaluate which trends are representative of regional processes. Lake-level history is reconstructed from changes in the relative abundance of openwater planktic taxa relative to benthic diatoms (e.g. Brugam et al., 1998; Schweger and Hickman, 1989; Wolin and Stone, 2010), as well as from changes in the abundance of pollen of aquatic plants. Shifts in the abundance of shallow water diatoms and macrophytes, identified from pollen, are interpreted in light of basin morphometry and how shallow water habitat availability is related to lake-level change (Stone and Fritz, 2004). The history of the terrestrial landscape is generated from pollen reconstructions of changes in vegetation, charcoal as an indicator of local fires, and grain size or weight percent sand as an index of the input of eolian material into the lake. Increased deposition of particles exceeding $0.2 \mathrm{~mm}$ in size implies input of sand by wind transport and reduced littoral shoreline vegetation that might reduce the entrainment of sand into the lake. In most cases, sand input into a lake basin is good evidence for reduced local moisture conditions, especially in drought-prone regions, such as the Sand Hills.

Early to middle Holocene (10,800-6400 cal. yr BP)

Early-Holocene lacustrine sediment is only present in the Twin Lakes; the diatom record from East Twin extends to over 10,000 cal. yr BP and West Twin to nearly 8300 cal. yr BP (Figure 3). The Beaver Lake core extends to $10,980 \pm 60{ }^{14} \mathrm{C}$ yr BP $(\sim 13,000$ cal. yr BP) at $979 \mathrm{~cm}$ depth, but the sediment from $\sim 655 \mathrm{~cm}$ to the base of the core (older than $\sim 5300 \mathrm{cal}$. yr BP) 

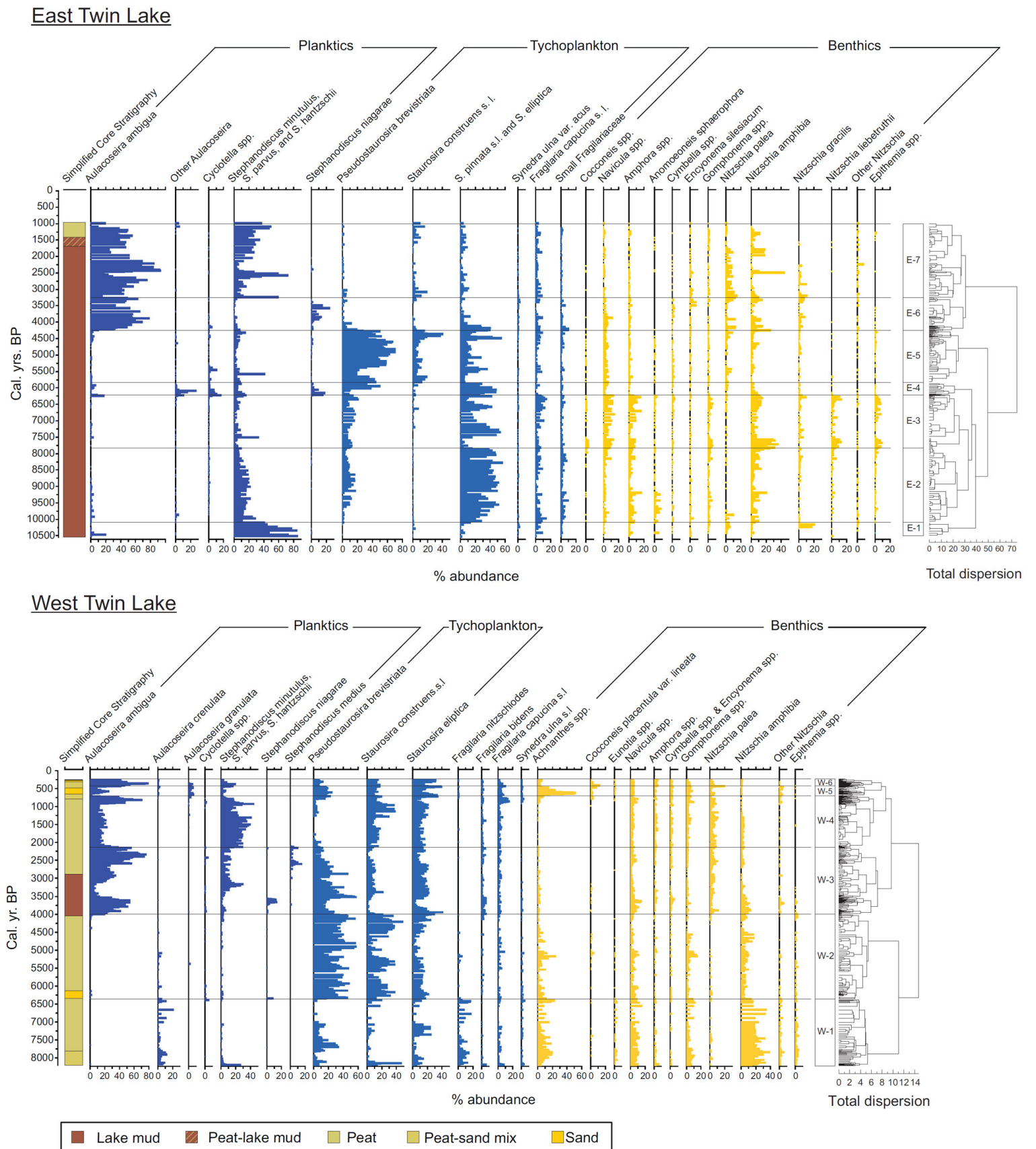

Figure 3. Sediment lithology and diatom stratigraphies of East Twin (top) and West Twin (bottom) located about 60 km southwest of Beaver Lake. Zonations are based on CONISS algorithm with significant clusters identified by the broken-stick method. The $\mathrm{x}$-axis represents relative abundance (\%), the $y$-axis age in calibrated years BP.

is an organic sand with abundant roots and rhizomes (Figure 4), which represents a fen environment, and these sediments were not analyzed. The very base of the East Twin Lake core (zone E-1) is dominated by the eutrophic planktic diatom species Stephanodiscus minutulus, S. parous, and S. hantzschii, an assemblage that suggests that the lake was moderately deep (>3 m) with high phosphorus concentrations (Bradbury, 1975, Brugam and Speziale, 1983). After $\sim 10,000$ cal. yr BP, the Twin Lakes (W-1 and E-2-E-3) are dominated by various benthic taxa (e.g. Nitzschia amphibia, Navicula spp., Amphora spp.), as well as tychoplanktic species, such as Pseudostaurosira brevistriata, Staurosira pinnata, and S. elliptica. Tychoplanktic species grow attached to benthic substrates but are commonly entrained into the plankton by mixing. The relatively low abundance of planktic species $(<20 \%)$ during this interval suggests that the lakes were moderately shallow. The inorganic and organic carbon concentrations in the sediments of both lakes are low $(<10 \%)$, which suggests relatively low algal productivity and substantial input of minerogenic sediment from the catchment. Eolian input, as indicated by the measurement of weight percent sand in the East Twin sediments, is moderate $(<30 \%)$, with short intervals of elevated values.

\section{Middle Holocene (6400-4000 cal. yr BP)}

The basal diatom assemblage in the Beaver Lake core (zone B-1, 6400-5750 cal. yr BP, Figure 4) is dominated by benthic taxa, such as Amphora libyca, Encyonema silesiacum, a variety of Nitzschia and Gomphonema species, as well as Anomoeo- 


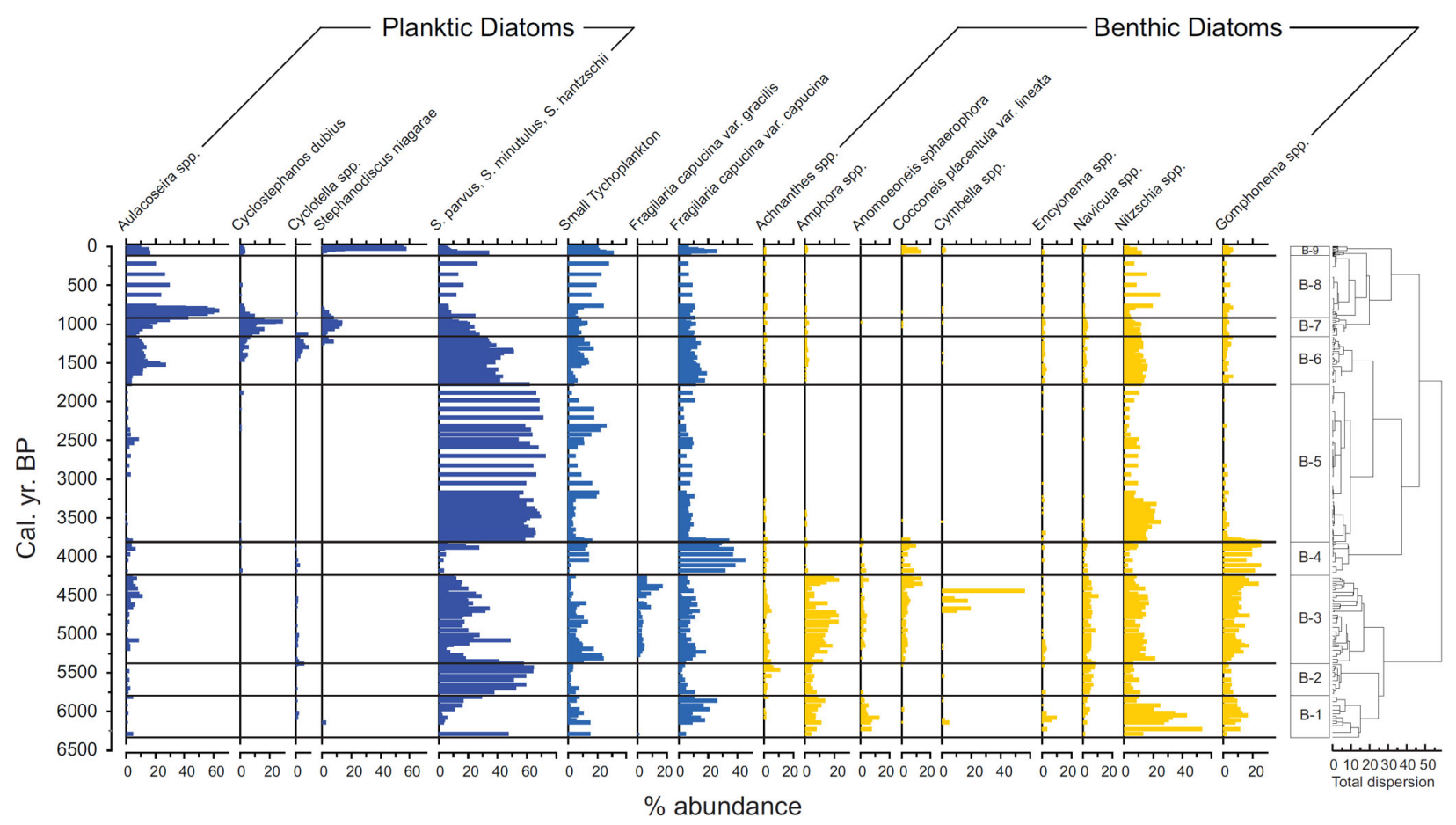

Figure 4. Beaver Lake diatom stratigraphy and sediment lithology (left) Diatom-based zonations are based on CONISS algorithm with significant clusters identified by the broken-stick method. The $x$-axis represents relative abundance (\%), the $y$-axis age in calibrated years BP. See Figure 3 for legend on lithology.

neis sphaerophora. Most of these species are alkaliphilous and characteristic of littoral habitats in lakes with moderate to high specific conductance (Krammer and Lange-Bertalot, 1988). At this time a similar suite of benthic diatoms also dominated the Twin Lakes (Figure 3), along with moderate percentages of tychoplanktic diatoms, such as Pseudostaurosira brevistriata, Staurosira construens, S. pinnata, and S. elliptica (zones W-2 and E-3). The benthic- and tychoplanktic-dominated assemblages suggest that the lakes were uniformly shallow and moderately high in conductivity and alkalinity.

Between 6300 and 5800 cal. yr BP all sites show a change in diatom species composition. In Beaver Lake (zone B-2, 58005400 cal. yr BP), the planktic species S. minutulus and S. parvus increase in abundance by more than $50 \%$. Whereas, in West Twin and East Twin Lake an increase of the tychoplanktic species Psedostaurosira brevistriata and Staurosira construens occurs beginning at 6300 and $6200 \mathrm{cal}$. yr BP, respectively, along with a marked decrease of benthic species, such as Navicula, Nitzschia, and Amphora (zones E-4 and W-2). The increase in planktic and tychoplanktic species relative to benthic taxa suggests an increase in lake depth at all sites.

At Beaver Lake, plankton declined to intermediate levels and benthic taxa increased slightly in zone B-3 (5400-4250 cal. yr BP). High abundances of Nitzschia, Gomphonema, and Amphora species at this time also suggest expansion of aquatic macrophytes (Hustedt, 1930; Spaulding and Kociolek, 2003). The simplest explanation for this transition is that lake levels were lower, although deeper than those prior to $6000 \mathrm{cal}$. BP. However, evidence of an interval of lowered lake-level after $\sim 5400$ cal. yr BP is not present in the Twin Lakes cores, which maintained dominance by tychoplankton throughout the period from $\sim 6300$ to 3800 cal. yr BP (zones W-2 and E-5). An alternative explanation for the increase in benthic diatoms in Beaver Lake is that this shift is a product of the basin morphometry and may represent continued lake-level rise over this period. The deepest portion of Beaver Lake is located to the east and adjacent to a shallow platform that separates Bea- ver Lake from Rat Lake (Figure 5); flooding of the embankment due to lake-level rise would increase benthic habitat. Thus the simplest explanation of the collective evidence is that effective moisture was moderately high throughout this interval, relative to conditions earlier in the middle Holocene. In the Beaver Lake core, an abrupt increase of tychoplanktic species, especially F. capucina, in zone B-4 ( 4250-3800 cal. yr BP) suggests a modest change in lake level.

The pollen record at the base of the Beaver Lake core (Figure 6) is dominated by taxa that are consistent with dry middle Holocene conditions and lowered lake level, specifically Amaranthaceae, which colonize mud flats and tolerate frequent drying, as well as moderate percentages $(20 \%)$ of grasses (Poaceae) and small percentages (5-20\%) of other herbaceous taxa (Ambrosia, Artemisia). This assemblage is characteristic of xeric grasslands with playas and shallow lakes that frequently dry out (Baker et al., 1990; Grimm, 2001). The high sand concentrations indicate high eolian inputs to the lake basin, and the low loss-on-ignition and high bulk density values represent minerogenic sediment (Figure 7).

Between 5300 and 3900 cal. BP Poaceae (zones B-3 and B-4) attained its highest abundance in the Beaver Lake pollen record, suggesting conditions conducive for the growth of warm-season grasses on the surrounding dune fields. The abundance of grasses and a concomitant decline of Amaranthaceae suggest lowered annual to decadal variability in precipitation, as favored by many prairie grass species, and generally wetter conditions and deeper lake levels than those earlier in the middle Holocene. Charcoal concentrations increased along with the rise of grasses, supporting the notion of dense vegetation, coupled with sufficient seasonal drought to fuel fire (Brown et al., 2005; Grimm et al., 2011). The subsequent increase in aquatic plants, including the emergent taxa Sagittaria and Typha, as well as submersed taxa, such as Myriophyllum and Potamogeton, suggests a perennial lake that was sufficiently shallow and sufficiently clear to support macrophyte growth. This pollen abundance of aquatic macrophytes is consistent with the high abundance of 


\section{Modern day shoreline}

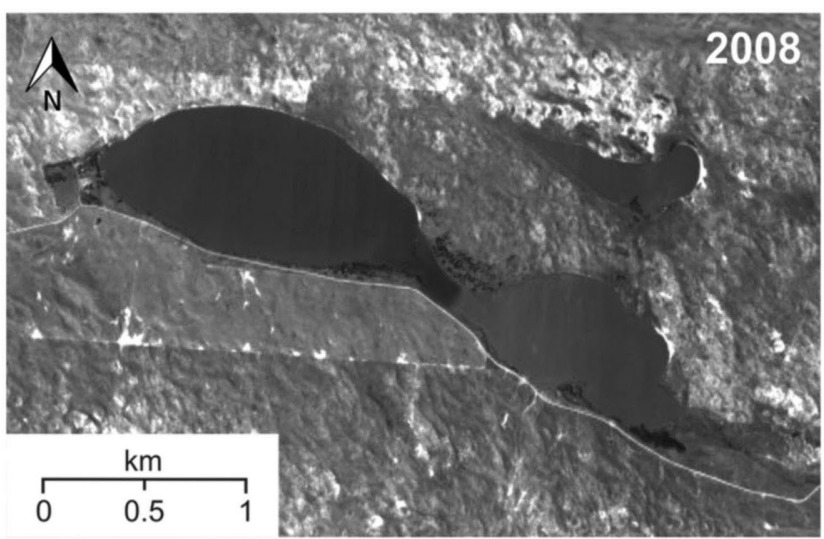

\section{Shoreline during Dust Bowl}

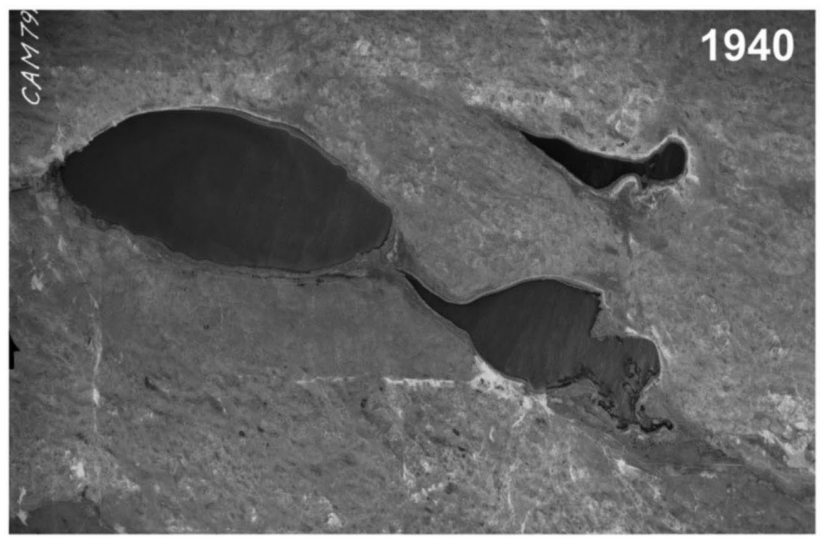

Figure 5. Comparison of aerial photographs from Beaver Lake (left) and Rat Lake (right). The left picture shows the modern lakes, the right picture shows the lakes during the Dust Bowl Drought. During drought, a shallow bank separates the two basins. This shallow area is flooded in wet times when the lakes coalesce.

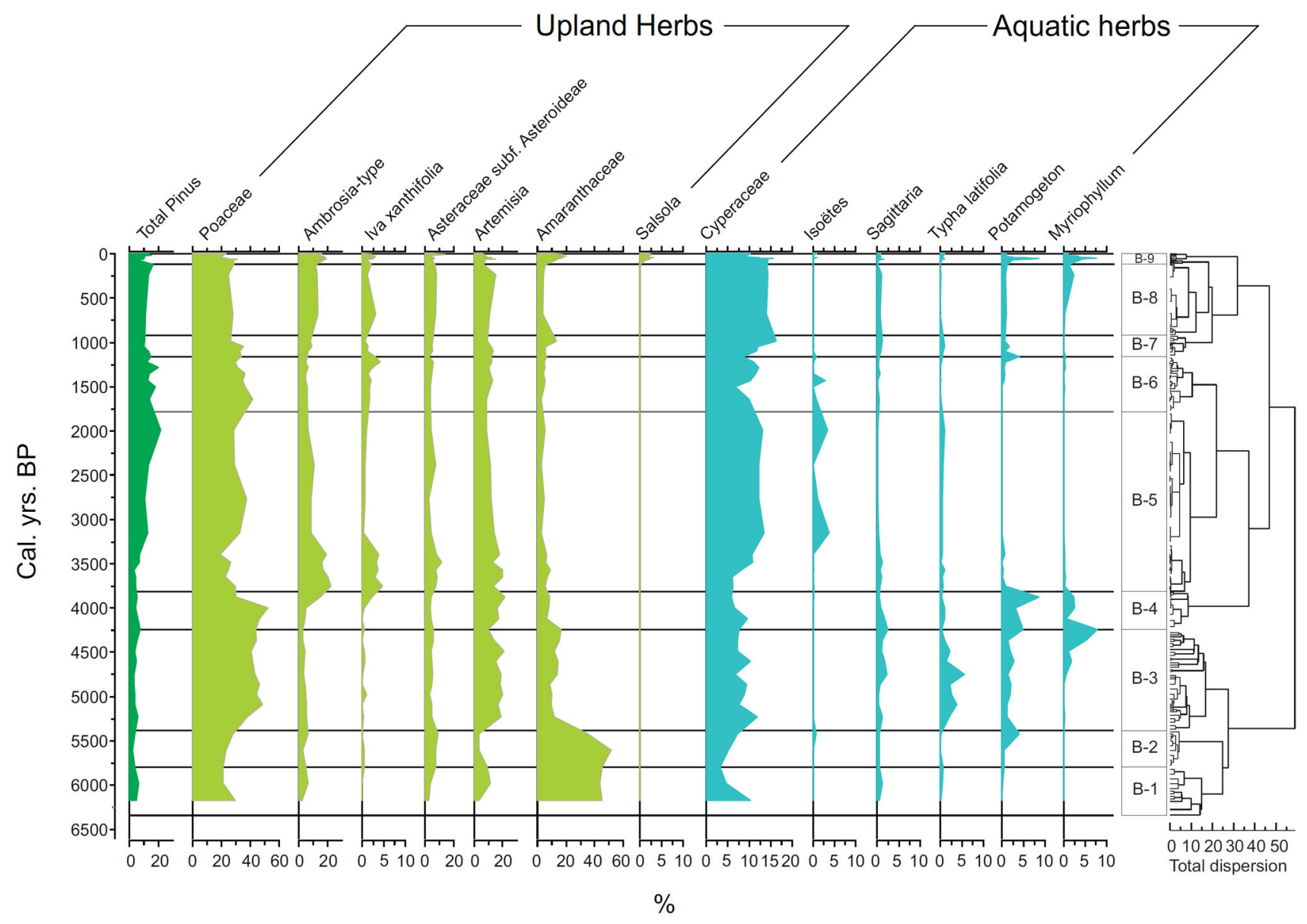

Figure 6. Beaver Lake pollen stratigraphy plotted against time (cal. yr BP). Horizontal lines indicate diatom-based zonation scheme (see Figure 4). Xaxis represents relative abundance (\%, note different scales).

benthic Nitzschia, Gomphonema, and Amphora diatom species. Elevated relative abundance of organic matter and calcium carbonate in the sediments likely reflects increased aquatic productivity. An abrupt decrease in grain size after 5800 cal. yr BP (zones B-2 and B-3) at the Beaver Lake site suggests reduced eolian input and dunes stabilized by grasses. Percent sand in the West Twin core similarly decreased after $\sim 5800 \mathrm{cal}$. yr BP. This interval of lowered eolian input to the Beaver Lake basin is followed by somewhat higher eolian deposition from 4200 to 3900 cal. yr BP. Despite the elevated sand flux, the expansion of submersed macrophytes in this interval in the Beaver Lake core suggests that the water was sufficiently clear that light penetrated into the water column and allowed the proliferation of aquatic plants. 
Beaver Lake

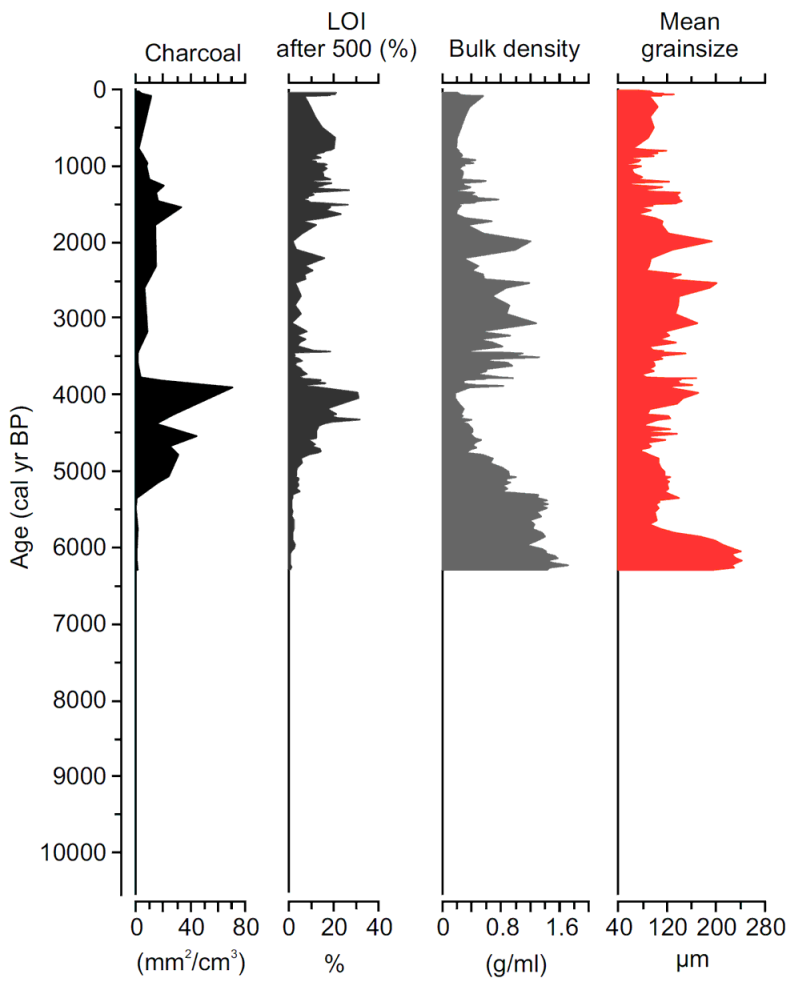

East Twin Lake

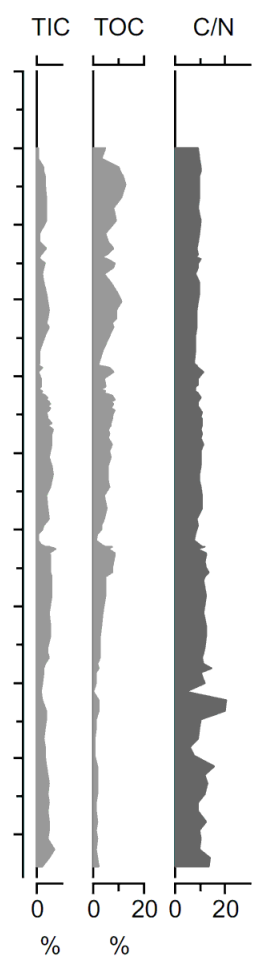

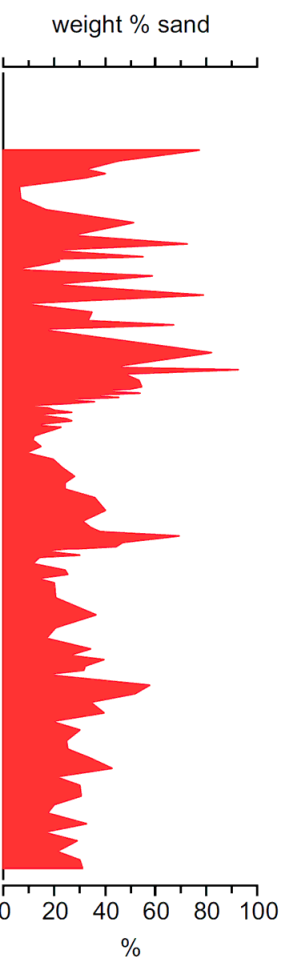

West Twin Lake

Figure 7. Stratigraphic profiles of grain size, weight \% sand, charcoal, as well as organic and inorganic carbon concentrations plotted against time (cal. yr BP).

\section{Late Holocene ( 4000-0 cal. yr BP)}

Probably the most dramatic shift in the Holocene diatom records occurred at the onset of the late Holocene. In Beaver Lake (Figure 4), at the transition from B-4 to B-5 ( 3800 cal. yr $\mathrm{BP})$, the abundance of planktic diatoms dramatically increased and persisted at high values $(>60 \%)$ for the following 2000 years (zones B-5 and B-6). A similar scenario, with an abrupt change from a benthic-dominated to planktic-dominated community, also is evident in the Twin Lakes stratigraphies (Figure 3), dated at 4100 and 4000 cal. yr BP, respectively. The difference in timing of this event can be related to differences in the response rates among lakes themselves (Fritz, 2008) and inherent dating errors of lake sediments. In all lakes, the rapid increase in the abundance of small Stephanodiscus species ( $S$. minutulus, S. parous, S. hantzschii) suggests deeper lake levels, as does a change in lithology in West Twin Lake from peat to carbonate-rich lake mud (Figures 3, 7). In the Twin Lakes, the rise in small Stephanodiscus spp. (zones E-6, W-3) is also accompanied by a rapid increase in Aulacoseira ambigua, a planktic taxon found in eutrophic to mesotrophic lakes (Brugam, 1983). Low percentages of epiphytic diatoms in the assemblage suggest reduced populations of aquatic macrophytes, likely because of the elevated lake level. In Beaver Lake, high percentages of planktic diatoms and a sheer lack of benthic diatoms in zone B-5 ( 3800-1800 cal. yr BP) suggests the highest lake-levels for the entire record, especially toward the top of the zone, between 2400 and 2000 cal. yr BP.

At the time of the large increase in planktic diatoms in the Beaver Lake core (3800 cal. yr BP, zone B-5), Poaceae relative abundance declined to values of $\sim 25 \%$, and Ambrosia and Iva xanthifolia percentages were elevated, especially in the lower part of the zone from $\sim 3800$ to 3300 cal. yr BP (Figure 6). In the northern Great Plains, Ambrosia characterizes overall drier periods, but probably exploits open ground during wetter years following severe drought (Grimm, 2001; Grimm et al., 2011). Iva xanthifolia typically grows on damp or drying soils (Stubbendieck et al., 1995). Together these suggest an interval of more frequent drought than previously, an interpretation consistent with lower charcoal concentrations indicating a reduction of fuel loads and fire frequency (Brown et al., 2005; Grimm et al., 2011). Organic matter is low, bulk density is high, and sediment sand content is higher in zone B-5 (Figure 7), indicating increased eolian input to Beaver Lake.

After 3300 cal. yr BP, Poaceae and charcoal concentrations increased slightly, and Ambrosia declined, suggesting somewhat wetter conditions. The rise in Pinus abundance undoubtedly is derived from long-distance transport of pine pollen as regional climate cooled and pine forests expanded along bluffs in the 'pine ridge' country to the west and north of the Sand Hills (Wright et al., 1985). The increase in the emergent aquatic species Isoëtes (quillwort) at this time probably represents Isoëtes melanopoda, the only species of this genus occurring today in the Nebraska Sand Hills (Steinauer and Rolfsmeier, 2003) and more generally in the northern and central Great Plains (Larson, 1993; Tayloret al., 1993). Isoëtes melanopoda can grow submerged, but is more characteristic of wet swales and temporary ponds (Larson, 1993; Steinauer and Rolfsmeier, 2003). In the Sand Hills, Isoëtes melanopoda occurs in two communities, Pond Marsh and Playa Wetland, both of which are described as 'palustrine emergent', the former 'primarily seasonally to semi-permanently flooded' and the latter 'temporarily and seasonally flooded' (Steinauer and Rolfsmeier, 2003). Although Isoëtes is uncommon today in the Sand Hills (Steinauer and Rolfsmeier, 2003) and northern Plains (Larson, 1993), it must have been fairly abundant at Beaver Lake $3500-1500$ years ago. Given the evidence from terrestrial pollen and charcoal of somewhat wetter conditions about $3300 \mathrm{cal}$. yr BP, the increased abundance of Isoëtes and the paucity of submerged 
aquatics (e.g. Potamogeton, Myriophyllum) relative to their abundance before and after this interval may reflect lake-level fluctuations that flooded the shallow sill between Beaver and Rat Lake, as described above (Figure 5). Cyperaceae increases in abundance after 3300 cal. yr BP. Most of this pollen probably derives from Schoenoplectus (bulrushes), which dominates the littoral zone around Beaver Lake today.

During the last 1800 years, a small decrease in overall lake level is suggested for Beaver Lake by the decreasing diatom abundance of Stephanodiscus spp., elevated percentages of Aulacoseira species, and a small increase in benthic taxa (Figure 4, zones B-6 to B-9). The lowered lake level likely increased wind-induced mixing and nutrient recycling, which favored the expansion of Aulacoseira. The relatively high abundance of the planktic Cyclostephanos dubius and Stephanodiscus niagarae from 1150 to 950 cal. yr BP (zone B-7) suggests a short interval of slightly higher lake levels, coupled with high phosphorus concentrations (Bennion et al., 1996; Hickel and Håkansson, 1987). Subsequently Aulacoseira species expanded and attained their highest abundance between 950 and 740 cal. yr BP (zone B-8). This interval falls within the Medieval Climate Anomaly (MCA), also evident in many other paleoclimatic studies across the Great Plains (e.g. Laird et al., 1998; Mason et al., 2004; Miao et al., 2007; Schmieder et al., 2011). Afterward, including during the 'Little Ice Age' interval, Aulacoseira species are replaced by Nitzschia spp. and small tychoplanktic Fragilariaceae, which suggest further lake-level decline (Schmieder et al., 2011).

At Twin Lakes (Figure 3), planktic abundance remains high throughout the late Holocene, and small Stephanodiscus spp. increase relative to Aulacoseira ambigua after $\sim 2000 \mathrm{yr}$ (zones E-7 and W-4). This pattern contrasts with trends observed at Beaver Lake, located $\sim 60 \mathrm{~km}$ to the east. Prior analyses of the late-Holocene stratigraphy of a larger number of sites across the Sand Hills suggest an east to west gradient in effective moisture during this period, with drier conditions in the east and wetter to the west (Schmieder et al., 2011). The uppermost sediments of East Twin Lake were not recovered during the coring process, however, at West Twin Lake the period after 900 cal. yr BP shows significant variation in species composition (W-5 and W-6). In particular, the expansion of Aulacoseira ambigua (end of zone W-4) and subsequently benthic Achnanthes spp. (zone W-5) suggests a progressive lowering of lakelevels from $\sim 900$ to $750 \mathrm{cal}$. yr BP, correlative with the latter part of the MCA through the onset of the 'Little Ice Age' period, followed by lake-level rise after 500 cal. yr BP (zone W-6).

Overall the Beaver Lake pollen record (Figure 6) of the last $2000 \mathrm{yr}$ shows relatively modest changes. Iva xantifolia is slightly more abundant during this period, and the macrophytes Potamogeton and Sagitarria increased slightly after 1250 cal. yr BP. Amaranthaceae percentages are elevated from 950-750 cal. yr BP (zone B-8), suggesting expansion of dried mud flats. The pollen data for somewhat drier conditions during the last $\sim 2000$ yr are consistent with the diatom evidence for slightly lowered lake levels, especially at the end of the MCA. However, values for average grain size in the Beaver Lake sediments were generally low after $\sim 2300$ (Figure 7), which suggests reduced eolian inputs, except for two short intervals ( 2090-1870 and 1500-1400 cal. yr BP).

The Beaver Lake core is the only site to contain 20th century sediments, and zone B-9, representing the last 70 years, is characterized by the dominance of the planktic diatom $S$. niagarae (Figure 4), which is common in eutrophic lakes in the northern USA and Canada (Brugam, 1983; Håkansson and Kling, 1989; Theriot,1987; Theriot and Stoermer, 1981), and likely reflects anthropogenic-induced eutrophication of the lake. The expansion of Salsola (Russian thistle), an introduced weed, in pollen zone B-9 (Figure 6) indicates European settlement and disturbance (Jacobson and Engstrom, 1989).

\section{Climate history from multiple proxies}

\section{Middle Holocene (6400-4000 cal. yr BP)}

Changes in lake level, terrestrial vegetation, fire, and eolian activity reconstructed from paleoecological and sedimentological data provide a complex picture of landscape changes in response to climate variation. In many cases the varied proxies respond synchronously and yield a coherent picture of changes in effective moisture and its landscape impacts. However, in some instances the proxies are clearly responding to different aspects of climate, and interpretation requires a more nuanced understanding of seasonal climatic influences on various aspects of the aquatic and terrestrial environment.

In the middle Holocene, prior to $\sim 6000 \mathrm{cal}$. yr BP, the aquatic and terrestrial proxies suggest extended drought that lowered water-tables and lake level and decreased grassland cover sufficiently to promote extensive migration of dunes and loess in the Nebraka Sand Hills and surrounding region. Beaver and the Twin Lakes were shallow basins dominated by benthic diatoms and accumulating peat throughout the middle Holocene; the pollen record of Beaver Lake indicates extensive mud flats during dry times that provided favorable habitat for Amaranthaceae. The high sand content at the base of the Beaver Lake core is consistent with a comprehensive synthesis of upland dune records and loess deposits (Goble et al., 2004; Miao et al., 2005, 2007), which shows widespread regional eolian activity from 10,000 to $6000 \mathrm{cal}$. yr BP in the Nebraska Sand Hills.

Beginning $~ 6000$ cal. yr BP, multiple indicators at all three sites indicate a regional increase in effective moisture. Increased abundances of planktic and tychoplanktic diatoms at all study sites, a transition from organic-rich sand to lake sediment in the Beaver Lake basin, as well as increased percentages of emergent and submersed macrophytes at the expense of Amaranthaceae in the Beaver Lake core indicate rising water levels regionally. Poaceae and other grassland herbs, such as Artemisia and Asteraceae, increased in abundance, and the rise in charcoal accumulation in Beaver Lake indicates sufficient fuel to favor grassland fires (Brown et al., 2005; Grimm et al., 2011). Reduced regional eolian activity (Miao et al., 2005, 2007; Nicholson and Swinehart, 2005) also suggests sufficient grassland cover to stabilize the dunes.

\section{Late Holocene ( 4000-0 cal. yr BP)}

By far the most dramatic change in the regional paleohydrology is a secular shift beginning $\sim 4000$ cal. yr BP in the diatom community composition at all three sites in the Sand Hills, specifically a shift to a regime of long-term dominance by planktic and tychoplanktic diatom species (Figure 8). At Beaver Lake, the onset of this period corresponds to diatom zone B-5, 3800-1800 cal. yr BP. The straightforward interpretation of the Beaver Lake proxies presented above (viz. diatoms suggesting deeper water; but pollen, charcoal, LOI, and grain size suggesting drier conditions) seems at first paradoxical, and, in fact, climate interpretations would differ fundamentally if aquatic and terrestrial proxies were studied independently of each other. Consistent with the terrestrial proxies and with the higher sand content of this interval, the regional eolian record shows a resurgence of dune and loess mobility beginning $\sim 4000$ cal. yr BP and persisting for about 2000 yr (Goble et al., 2004; Miao et al., 2007; Nicholson and Swinehart, 2005). The Wauneta loess section to the southwest of the Sand Hills shows soil development, and thus moist conditions, at $\sim 6600-4000$ cal. yr BP, followed by two episodes of eolian activity and thus drier conditions, centered on 3800 and 2500 cal. yr BP and separated by a phase of weak soil development. Soil development then followed until 800 cal. yr BP (Miao et al., 2007). Interpretation of this section agrees remark- 


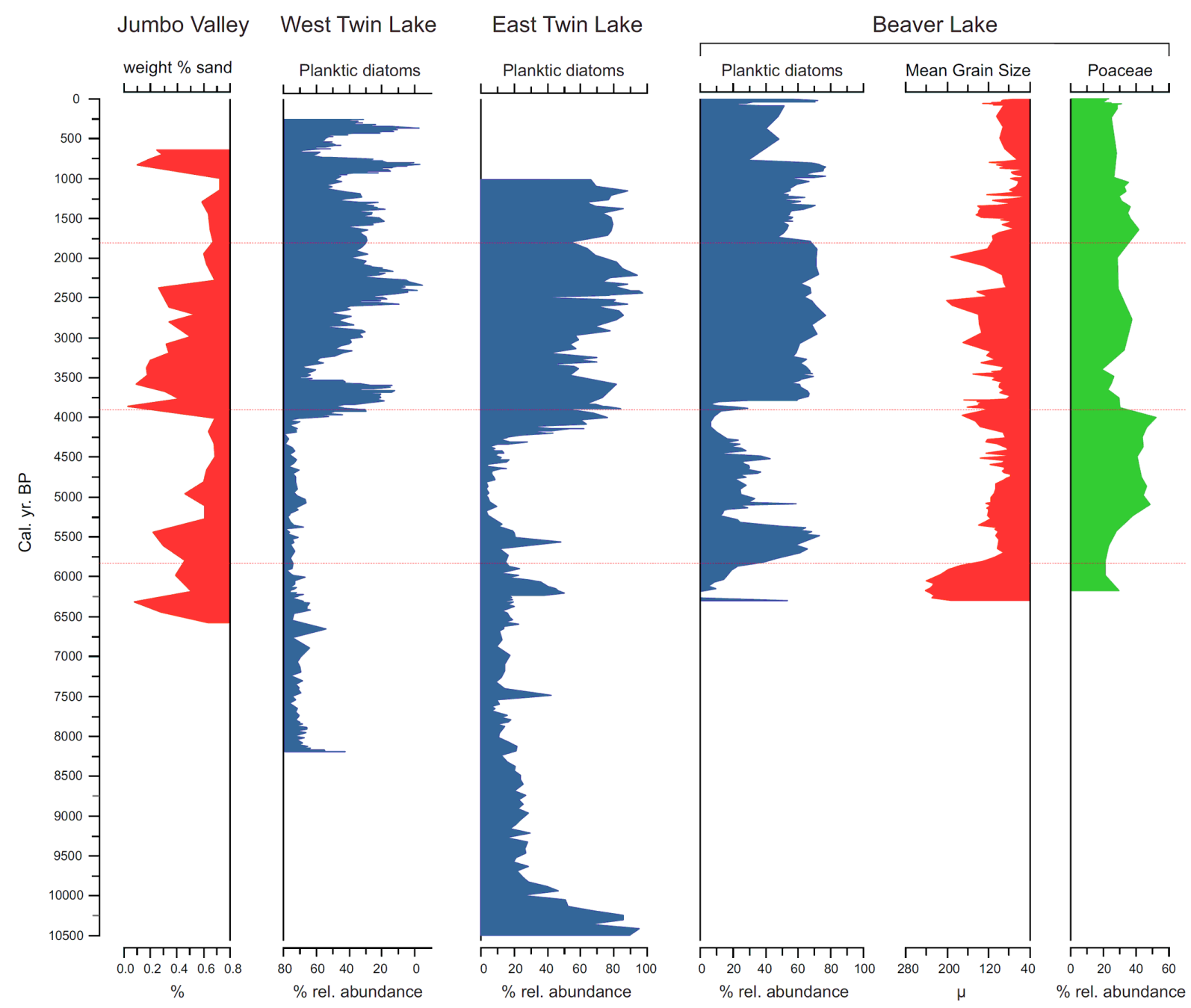

Figure 8. Qualitative comparison of changes in effective moisture between major proxies from Beaver Lake, as well as from Jumbo Valley (after Nicholson and Swinehart, 2005) and the Twin Lakes. The three graphs on the right show percent planktic diatoms as an indicator of changes in lake-level; the center graph to the right illustrates results from the grain size analysis as a proxy for eolian input, while the graph on the far right reflects shifts in moisture based on pollen analysis. Red lines represent qualitative interpretations of significant thresholds that indicate changes in effective moisture. For regional comparison we included the weight percent sand stratigraphy from Jumbo Valley, as well as planktic diatom abundance from East and West Twin, both located about $60 \mathrm{~km}$ west of Beaver Lake.

ably well with our climatic reconstruction from the terrestrial proxies from Beaver Lake that also suggest a dry interval commencing $\sim 3800$ cal. yr BP. Similarly, weight \% sand data from the neighboring Jumbo Fen (Figure 8), indicates lowered water level and increased eolian activity after $\sim 4000$ cal. yr BP (Nicholson and Swinehart, 2005).

The question is how to reconcile the diatom evidence for higher lake levels with a period of drier climate as inferred from terrestrial proxies during the late Holocene (Figure 8). One explanation is that the regional rise in the water-table and hence in lake levels is a product of the blockage of paleodrainage channels by migrating sand during a dry interval. Loope et al. (1995) provided evidence of multiple episodes of dune blockage events and subsequent water-table rise in the Crescent Lake Wildlife Refuge of the Nebraska Sand Hills (Figure 1d), including a coincident interval of lake-level increase at $\sim 4000$ cal. yr BP. Today, dozens of lakes occur in the vicinity of Beaver and Rat Lakes and in the region adjoining the Twin Lakes, and small tributaries from the North Loup River to the south and the Niobrara River to the north drain both areas. Thus, mobilization of dunes during arid periods could have blocked regional paleo-drainage channels at times in the past. A hypothesis of water-table rise as a result of geomorphic pro- cesses is consistent with the evidence for a secular change in lake level that persisted throughout the late Holocene at all three sites. Yet, blockage and subsequent sealing of dune dams by organic matter accumulation does not seem a particularly likely explanation given the coincidence of lake-level shifts among basins in different geomorphic settings. Unfortunately, in the absence of detailed geomorphic studies of the lake basins studied here, we cannot effectively evaluate the hypothesis of local water-table rise by dune blockage as a cause of the intervals of lake-level increase.

A second explanation that is not mutually exclusive is that dry conditions during the spring and early summer decreased vegetative cover yet increased groundwater recharge, because of reduced evapotranspiration. In the northern Great Plains today, lake levels are especially responsive to winter precipitation, because summer precipitation is mostly evapotranspired (Winter and Rosenberry, 1995). The Beaver Lake charcoal data suggest low fuel loads and thus sparse vegetative cover after $\sim 3800$ cal. yr BP (Figure 7), consistent with the regional and local evidence of increased eolian activity. This reduction of grassland cover would decrease evapotranspiration, and because groundwater recharge is equivalent to infiltration minus evapotranspiration (van der Kamp et al., 2003), any subsequent rain- 
fall or snowmelt would quickly absorb into the highly permeable sands and recharge the groundwater-table that supplies interdunal lakes and wetlands. In the Nebraska Sand Hills, where evaporation exceeds precipitation by $\sim 600 \mathrm{~mm} / \mathrm{yr}$ (Winter, 1986), groundwater inflow is a major component of water balance in regional lakes (Zlotnik et al., 2007). Thus, a logical hypothesis for the transition at 3800 cal. yr BP is that climate became drier throughout much of the growing season, which reduced vegetative cover and therefore evapotranspiration, causing groundwater and lake levels to rise. Because the sandy soils of the Sand Hills region have a low water-holding capacity, winter precipitation and snowmelt cannot buffer summer drought as it can in areas with heavier soils. Thus, drought during the growing season would be required to decrease vegetative cover. It is not clear whether total annual precipitation was lower during this interval or whether the seasonal timing of precipitation was shifted away from spring and early summer, the primary growing season.

A final possibility is that a shift in the frequency and duration of drought may have contributed to the differential responses of the hydrological and eolian systems in the late Holocene. High variability in effective moisture, with recurrent summer droughts of multiple years, interspersed with moderately wet years could maintain the regional water-table height, yet create favorable conditions for reduced grass cover and increased eolian activity. In contrast, persistent drought during the height of the middle Holocene would have both lowered groundwater-tables and reduced vegetation density. Consistent with this hypothesis, the regional loess record (Miao et al., 2007) and the eolian record from nearby Jumbo Valley (Nicholson and Swinehart, 2005), suggest that eolian activity in the late Holocene was more episodic than that of the early to middle Holocene, and the eolian records from East Twin and Beaver Lakes similarly show considerable high-frequency variability in this interval.

At present the available evidence does not allow us to determine the cause of the lake-level rise at the onset of the late Holocene. Nonetheless, the divergent responses of the eolian and hydrologic systems to changes in effective moisture in the late Holocene, particularly from $\sim 3800$ to 1800 cal. yr BP, suggest that some aspect of climate was fundamentally different from patterns in the middle Holocene. In any case, it is clear that the late Holocene was not nearly as dry as earlymiddle Holocene intervals prior to $6000 \mathrm{cal}$. yr BP, when Beaver Lake and many other Sand Hills lakes did not continuously hold standing water and eolian activity was widespread and persistent.

\section{Summary and conclusions}

A combined analysis of diatoms, pollen, grain size, and bulk sediment chemistry from early- to late-Holocene lake sediments at three sites in the central Sand Hills of Nebraska reveals long-term changes in effective moisture. The basins have accumulated sediments since the Lateglacial or the early Holocene. East Twin Lake was moderately deep at the onset of the Holocene, whereas the other two basins (West Twin Lake and Beaver Lake) were shallower and accumulated peat. From 10,000 to $\sim 6000$ cal. yr BP, all basins were relatively shallow, and benthic and tychoplanktic diatoms dominated the Twin Lakes. Eolian flux was moderately high, and the middle Holocene pollen assemblage at the base of the Beaver Lake core suggests xeric grasslands and abundant mud flats in the shallow lake basins. Thus, both aquatic and terrestrial indicators suggest that effective moisture was low and that this was the driest time in the Holocene. After about 6000 cal. yr BP, all three sites suggest elevated effective moisture. Lake-level rise is indicated by increases in planktic and tychoplanktic diatoms relative to benthic taxa. Increased grass pollen and charcoal abundance and decreased eolian flux suggest stabilized dunes with dense vegetation sufficient to fuel local fires.

A major hydrologic shift is recorded at $\sim 4000$ cal. yr BP, with substantial lake-level rise in all basins, yet decreased grass cover and fire and increased eolian activity. Dune-dam blockage of paleo-drainage channels, reduced vegetative cover and therefore reduced evapotranspiration, and/or changes in the frequency and duration of drought may have contributed to the water-table rise at this time. During the last $\sim 2000 \mathrm{yr}$, several short-term fluctuations in lake level were characteristic, including an interval of drought coincident with the latter part of the MCA. Overall this study highlights the complexity of hydrologic, vegetation, and eolian patterns during the Holocene and the need for multiple proxies in order to develop a nuanced understanding of how changes in seasonality, the duration, and the frequency of climatic and environmental drivers influence the landscape in dynamic eolian regions, such as the Nebraska Sand Hills.

Acknowledgments - This work was made possible by the Sand Hills Biocomplexity Project at the University of Nebraska-Lincoln (NSF-02-167) and a NSF grant (EAR06-09983) to SCF and ECG. Additional funding was provided through the University of Nebraska departmental summer fellowship, Yatkola-Edwards Grant of theNebraska Geological Society, and the Great Plains Studies Research Grant-in-Aid. Aaron Young provided field assistance; Jeffery Stone, Karlyn Westover, Avery Shinemann, as well as William Hobbs helped with the data analysis and provided ideas that improved the outcome of this paper.

\section{References}

Baker RG, Chumbley CA, Witinok PM et al. (1990) Holocene vegetational changes in eastern Iowa. Journal of the Iowa Academy of Science 97: 167-177

Bennett DM, Fritz SC, Holz J et al. (2007) Evaluating climatic and non-climatic influences on natural and man-made lakes in Nebraska, USA. Hydrobiologia 591: 103-115

Bennett KD (2002) Documentation for psimpoll 4.10 and pscomb 1.03; online @ http://www.kv.geo.uu.se/psimpoll.htmlBennion H, Juggins S and Anderson NJ (1996) Predicting epilimnetic phosphorus concentrations using an improved diatom-based transfer function, and its application to lake eutrophication management. Environmental Science \& Technology 30: 2004-2007.

Blaauw M and Christen JA (2011) Flexible paleoclimate agedepth models using an autoregressive gamma process. Bayesian Analysis 6: 457-474.

Bleed AS and Ginsberg M (1998) Lakes and wetlands. In: Bleed A and Flowerday C (eds) An Atlas of the Sand Hills. Resource Atlas 5b. Lincoln: Conservation and Survey Division, University of Nebraska-Lincoln, pp. 115-122.

Bradbury JP (1975) Diatom stratigraphy and human settlement in Minnesota. Geological Society of America, Special Paper 171, $74 \mathrm{pp}$.

Brown KJ, Clark JS, Grimm EC et al. (2005) Fire cycles in North American interior grasslands and their relation to prairie drought. Proceedings of the National Academy of Sciences of the United States of America 102: 8865-8870.

Brugam RB (1983) The relationship between fossil diatom assemblages and limnological conditions. Hydrobiologia 98: 223-235.

Brugam RB and Speziale BJ (1983) Human disturbance and the paleo-limnological record of change in the zooplankton community of Lake Harriet, Minnesota. Ecology 64: 578-591.

Brugam RB, McKeever K and Kolesa L (1998) A diatom-inferred water depth reconstruction for an Upper Peninsula, Michigan, Lake. Journal of Paleolimnology 20: 267-276.

Dean WE (1974) Determination of carbonate and organic matter in calcareous sediments and sedimentary rocks by loss-on-ig- 
nition: Comparison with other methods. Journal of Sedimentary Petrology 44: 242-248.

Dean WE, Ahlbrandt TS, Anderson RY et al. (1996) Regional aridity in North America during the middle Holocene. The Holocene 6: 145-155.

Fægri K, Iversen J, Kaland PE et al. (1989) Textbook of Pollen Analysis. 4th edition. Chichester: John Wiley \& Sons.

Fritz SC (2008) Deciphering climatic history from lake sediments. Journal of Paleolimnology 39: 5-16.

Fritz SC, Ito E, Yu Z et al. (2000) Hydrologic variation in the northern Great Plains during the last two millennia. Quaternary Research 53: 175-184.

Goble RJ, Mason JA, Loope DB et al. (2004) Optical and radiocarbon ages of stacked paleosols and dune sands in the Nebraska Sand Hills, USA. Quaternary Science Reviews 23: 1173-1182.

Grimm EC (1987) CONISS: A FORTRAN 77 program for stratigraphically constrained cluster analysis by the method of incremental sum of squares. Computers \& Geosciences 13: 13-35.

Grimm EC (2001) Trends and paleoecological problems in the vegetation and climate history of the Northern Great Plains, U.S.A. Biology and Environment: Proceedings of the Royal Irish Academy 101B: 47-64.

Grimm EC (2011) High-resolution age model based on AMS radiocarbon ages for Kettle Lake, North Dakota, USA. Radiocarbon 53: 39-53.

Grimm EC, Donovan JJ and Brown KJ (2011) A high-resolution record of climate variability and landscape response from Kettle Lake, northern Great Plains, North America. Quaternary Science Reviews 30: 2626-2650.

Grimm EC, Maher LJ, Jr and Nelson DM (2009) The magnitude of error in conventional bulk-sediment radiocarbon dates from central North America. Quaternary Research 72: 301-308.

Håkansson H and Kling H (1989) A light and electron microscope study of previously described and new Stephanodiscus species (Bacillariophyceae) from central and northern Canada lakes, with ecological notes on the species. Diatom Research 4: 269-288.

Hickel B and Håkansson H (1987) Dimorphism in Cyclostephanos dubius (Bacillariophyta) and the morphology of initial valves. Diatom Research 2: 35-46.

Hustedt F (1930) Die Süsswasserflora Mitteleuropas. Heft 10 Bacillariophyta (Diatomeae). 466 pp.

Jacobson HA and Engstrom DR (1989) Resolving the chronology of recent lake sediments: An example from Devils Lake, North Dakota. Journal of Paleolimnology 2: 81-98.

Juggins S (2009) C2 User Guide. Software for Ecological and Palaeoecological Data Analysis and Visualisation. Newcastle upon Tyne: University of Newcastle, $69 \mathrm{pp}$.

Krammer K and Lange-Bertalot H (1986) Bacillariophyceae. 1. Teil: Naviculaceae. In: Ettl H, Gärtner G, Gerloff J and et al. (eds) Süsswasserflora von Mitteleuropa, Band 2/1. Stuttgart/ New York: Gustav Fischer Verlag, 876 pp.

Krammer K and Lange-Bertalot H (1988) Bacillariophyceae. 2. Teil: Bacillariaceae, Epithemiaceae, Surirellaceae. In: Ettl H, Gärtner G, Gerloff J and et al. (eds) Süsswasserflora von Mitteleuropa, Band 2/2. Stuttgart/New York: Gustav Fischer Verlag, 596 pp.

Krammer K and Lange-Bertalot H (1991a) Bacillariophyceae. 3. Teil: Centrales, Fragilariaceae, Eunotiaceae. In: Ettl H, Gärtner G, Gerloff J and et al. (eds) Süsswasserflora von Mitteleuropa, Band 2/3. Stuttgart/New York: Gustav Fischer Verlag, $576 \mathrm{pp}$.

Krammer K and Lange-Bertalot H (1991b) Bacillariophyceae. 4. Teil: Achnanthaceae, Kritische Ergänzungen zu Navicula (Lineolatae) und Gomphonema, Gesamtliteraturverzeichnis
Teil 1-4. In: Ettl H, Gärtner G, Gerloff Jand et al. (eds) Süsswasserflora von Mitteleuropa, Band 2/4. Stuttgart/New York: Gustav Fischer Verlag, 437 pp.

Laird KR, Fritz SC, Cumming BF et al. (1998) Early-Holocene limnological and climatic variability in the Northern Great Plains. The Holocene 8: 275-285.

La Baugh JW (1986) Limnological characteristics of selected lakes in the Nebraska Sandhills,. USA, and their relations to chemical characteristics of adjacent ground water. Journal of Hydrology 86: 279-298.

Larson GE (1993) Aquatic and Wetland Vascular Plants of the Northern Great Plains. United States Department of Agriculture, Forest Service, General Technical Report RM-238. Fort Collins CO: Rocky Mountain Forest and Range Experiment Station, $681 \mathrm{pp}$.

Loope DB and Swinehart JB (2000) Thinking like a dune field: Geologic history in the Nebraska Sand Hills. Great Plains Research 10: 5-35.

Loope DB, Swinehart JB and Mason JP (1995) Dune-dammed paleovalleys of the Nebraska Sand Hills: Intrinsic versus climatic controls on the accumulation of lake and marsh sediments. Geological Society of America Bulletin 107: 396-406.

McCarraher DB (1977) Nebraska's Sandhills Lakes. Lincoln: Nebraska Game and Parks Commission.

Mason JA, Swinehart JB, Goble RJ et al. (2004) Late Holocene dune activity linked to hydrological drought, Nebraska Sand Hills, USA. The Holocene 14: 209-217.

Miao X, Mason JA, Goble RJ et al. (2005) Loess record of dry climate and Aeolian activity in the early to mid Holocene, central Great Plains, North America. The Holocene 15: 339-346

Miao X, Mason JP, Swinehart JB et al. (2007) A10,000 year record of dune activity, dust storms, and severe drought in the central Great Plains. Geology 35: 119-122.

Muhs DR and Maat PB (1993) The potential response of eolian sand to greenhouse warming and precipitation reduction on the Great Plains of the U.S.A. Journal of Arid Environments 25: 351-361.

Muhs DR, Stafford TWJ, Been J et al. (1997) Holocene eolian activity in the Minot Dune Field, North Dakota. Canadian Journal of Earth Science 34: 1442-1459.

Nicholson BJ and Swinehart JB (2005) Evidence of Holocene climate change in a Nebraska Sandhills wetland. Great Plains Research 15: 45-67.

Patrick R and Reimer C (1966) The Diatoms of the United States Exclusive of Alaska and Hawaii. Vol. 1. Philadelphia: The Academy of Natural Sciences of Philadelphia, Monograph 13, 668 pp.

Patrick R and Reimer C (1975) The Diatoms of the United States Exclusive of Alaska and Hawaii. Vol. 2, Part 1. Philadelphia: The Academy of Natural Sciences of Philadelphia, Monograph 13, 213 pp.

Reimer PJ, Baillie MGL, Bard E et al. (2009) IntCal09 and Marine09 radiocarbon age calibration curves, $0-50,000$ years cal BP. Radiocarbon 51(4): 1111-1150.

Schmieder J (2009) Mid-to-late Holocene multi-proxy climatic and hydrologic variability in the north-central Sand Hills, NE, USA. 11-73 PhD dissertation, University of Nebraska - Lincoln, 216 pp.

Schmieder J, Fritz SC, Swinehart JB et al. (2011) A regional-scale climate reconstruction of the last 4000 years from lakes in the Nebraska Sand Hills, USA. Quaternary Science Reviews 30: 1797-1812.

Schweger CE and Hickman M (1989) Holocene paleohydrology, central Alberta: Testing the general circulation model climate simulations. Canadian Journal of Earth Sciences 26: 1826-1833. 
Spaulding SA and Kociolek JP (2003) Freshwater diatoms (Bacillariophyceae). In: Goodman S and Benstead J (eds) Natural History of Madagascar. University of Chicago Press.

Steinauer G and Rolfsmeier S (2003) Terrestrial Natural Communities of Nebraska (Version III-June 30 , 2003). Lincoln: Nebraska Natural Heritage Program, Nebraska Game and Parks Commission.

Stone JR and Fritz SC (2004) Three-dimensional modeling of lacustrine diatom habitat areas: Improving paleolimnological interpretation of planktic:benthic ratios. Limnology and Oceanography 49: 1540-1548.

Stubbendieck J, Friisoe GY and Bolick MR (1995) Weeds of Nebraska and the Great Plains, Second Edition. Lincoln: Nebraska Department of Agriculture.

Stuiver M and Reimer PJ (1993) Extended ${ }^{14} \mathrm{C}$ data base and revised CALIB $3.0{ }^{14} \mathrm{C}$ age calibration program. Radiocarbon 35 : 215-230.

Swinehart JB (1990) Windblown deposits. In: Bleed A and Flowerday C (eds) An Atlas of the Sand Hills. Resource Atlas 5b. Lincoln: Conservation and Survey Division, University of Nebraska-Lincoln, pp. 43-56.

Taylor WC, Luebke NT, Britton DM et al. (1993) Isoëataceae Reichenbach. Quillwort family. In: Flora of North America Editorial Committee (eds) Flora of North America North of Mexico. Volume 2. Pteridiphytes and Gymnosperms. New York: Oxford University Press, pp. 64-75.

Theriot E (1987) Principal component analysis and taxonomic interpretation of environmentally related variation in silicification in Stephanodiscus (Bacillariophyceae). British Phycological Journal 22: 359-373.

Theriot E and Stoermer EF (1981) Some aspects of morphological variation in Stephanodiscus niagarae (Bacillariophyceae). Journal of Phycology 17: 64-72. van der Kamp G, Hayashi M and Gallén D (2003) Comparing the hydrology of grassed and cultivated catchments in the semi-arid Canadian prairies. Hydrological Processes 17: 559-575.

Wilhite DA and Hubbard KG (1998) Climate. In: Bleed A and Flowerday C (eds) An Atlas of the Sand Hills. Resource Atlas 5b. Lincoln: Conservation and Survey Division, University of Nebraska-Lincoln, pp. 17-28.

Winter TC (1986) Effect of ground-water recharge on configuration of the water table beneath sand dunes and on seepage in lakes in the Sandhills of Nebraska, U.S.A. Journal of Hydrology 86: 221-237.

Winter TC and Rosenberry DO (1995) The interaction of ground water with prairie pothole wetlands in the Cottonwood Lake area, East-Central North Dakota, 1979-1990. Wetlands 15: 193-211.

Wolin JA and Stone JR (2010) Diatoms as indicators of waterlevel change in freshwater lakes. In: Stoermer EF and Smol JP (eds) The Diatoms: Applications for the Environmental and Earth Sciences (2nd Edition). Cambridge University Press, pp. 174-185.

Woodhouse CA and Overpeck JT (1998) 2000 years of drought variability in the Central United States. Bulletin of the American Meteorological Society 79: 2693-2714.

Wright HE, Almendinger JC and Grüger J (1985) Pollen diagram from the Nebraska Sandhills and the age of the dunes. Quaternary Research 24: 115-120.

Zlotnik VA, Burbach M, Swinehart JB et al. (2007) A case study of direct push methods for aquifer characterization in dunelake environments. Environmental and Engineering Geology 13: 205-216. 